\title{
The Contract of Marriage and Its Purposes from Islamic Perspective
}

\author{
Hayatullah Laluddin ${ }^{1}$, Norhoneydayatie Abdul Manap ${ }^{1}$, Ahmad Azam bin Mohd. Shariff ${ }^{2}$, Ahmad bin \\ Muhammad Husni ${ }^{1}$, Zuliza Mohd. Kusrin ${ }^{1}$, Ibnor Azli Ibrahim ${ }^{1} \&$ Nazura Abdul Manap ${ }^{2}$ \\ ${ }^{1}$ Shari'ah Departments, Universiti Kebangsaan Malaysia, National University of Malaysia, Malaysia \\ ${ }^{2}$ Faculty of Law, Universiti Kebangsaan Malaysia, National University of Malaysia, Malaysia \\ Correspondence: Hayatullah Laluddin, Shari'ah Departments, Universiti Kebangsaan Malaysia, National \\ University of Malaysia, Malaysia. E-mail: hayatul67@yahoo.com
}

Received: July 28, 2013 Accepted: November 20, 2013 Online Published: December 29, 2013

doi:10.5539/ass.v10n2p139 URL: http://dx.doi.org/10.5539/ass.v10n2p139

\begin{abstract}
The prosperity and success of a society heavily depends on the strength of the relation of its individual members, thus family constituting the fundamental unit of the structure of society provides the avenue for initiation of such relation among the individual members. Marriage as the only process through which families are brought into existence can play a very significant role in formulation of a good and cordial relation between individual at the micro level in the society hence, extending it to macro level. Therefore, this paper attempts to delineate on the significance of marriage in Islam, its purposes and role, in creation of cordial relation among the members of the society. This paper using an analytical method concludes that marriage leads to formation of cordial relation among family members hence result an integrated social relation network in the society.
\end{abstract}

Keywords: marriage contract, Islam, family, spouses, social relation, society

\section{Introduction}

Marriage is a contract between a man and a woman, whom he can legally marry, with the aims of establishing a joint life and procreation. The Arabic term 'zawaj' ("marriage") stand for association and coming together. This term is used in the Holy Quran in the same sense of bringing together or of being together. Besides, the term 'nikah' ("marriage") is defined as "a purposeful contract to obtain and possess an enjoyment." It also embodies the meaning of coming together or assembling. However, it generally signifies marriage. The term zawj is used in the Quran implying a pair or a mate (Mohammed, 2012). The word: 'nikah' is mentioned in al-Quran in several places like in Surah al-Baqarah verse 221, 230, 232; Surah al-Nisa' verse 3, 22, 25; Surah an-Nur verse 3, 32, 33 and Surah al-Ahzab verse 49. (Ibrahim, 1997) In fact, marriage and pairing are of the laws that God has passed for his creatures. However, pairing generally apply to animal and vegetation, whereas, marriage as a suitable system through which man's dignity and honor can be maintained is specifically assigned to man, a sign of his distinction and superiority over other creation. (al-Tuwaijiri \& Muhammad, n. d., p. 4) Marriage or nikah in Islam is a highly religious sacred covenant which legalize sexual intercourse and hence, the procreation of children. It reflects 'the practical bent of Islam' for it combines the nature of both worship (ibadat) and social relations (muamalat). Thus, marriage ziwaj imply a process through which a man and woman by means of a particular form of contract ('aqd) are united and live together legitimately as husband and wife.

Marriage is the only process through which families are brought into existence; therefore it is of magnificent importance for human society. It is due to the fact that family constitutes the fundamental unit of the structure of society, that the Prophet (PBUH), insisted his followers with capability of marriage to enter marriage contract. However, it should be born in mind that there are certain procedures and rules that Shari'ah has prescribed for the process of entering into the contract of marriage which has to be abided. Among these procedures are verbal consent of spouses, presence of a guardian, and presence of two witnesses. (al-Tuwaijiri \& Muhammad, n. d., p. 4) This is necessary to ensure the smooth running of the family life and its proper functioning and that both husband and wife live in a sphere that is dominated by love, security, and tranquility.

Islam, strongly advocate marriage and there is no room for celibacy in the Islamic social framework, as is the case with the Roman Catholic priests and nuns, (Mohammed, 2012) the notion recently attracted a great deal of criticism. Missionary Priest Fr Shay Cullen who is of Irish origin, and who has won three Nobel Prizes nomination for his work saving children from sexual abuse in the Philippines for the past 40 years, predict the abolishment of 
celibacy by church sooner or later due to perceiving it as a mere 'business arrangement' for the Catholic Church and not as a commandment of God. He viewed celibacy as a lifeless law imposed by mere human beings not God. The prophet (PBUH) has said, "In Islam there is no room for celibacy" (Muhammad, 1994). This saying of the prophet implies that, marriage is a religious duty and social necessity and provides a moral safeguard for the behavior of the individual members of society. In fact, marriage provides a channel through which one can fulfill his/her sexual needs and regulates them in a lofty manner hence, avoiding becoming a slave to his/her desires. It is the only legitimate or halal way through which man and a woman indulge in intimacy. However, Islam takes a middle position in respect of sexual relations. It does not condemn it totally as certain religions do. In the same time it does not allow it freely. It rather requires its followers to control and regulate their desire hence, preserving their dignity and not behaving like animals in respect of their sexual relation. Thus, marriage can be categorized as a social necessity by mean of which families, the fundamental units of the structure of the society can be established.

\section{Significance of Marriage in Islam}

The worth and significance of the institution of marriage is evident from the fact that it provides a healthy environment for the maintenance of cordial relations between the spouses and reciprocal love between them. It also helps one to maintain his/her chastity and guard him/herself against committing the prohibited acts. Likewise, it represents the best means of reproduction, multiplication and preservation of the family lineage. Therefore, Islamic law prescribes several requirements or conditions which are fundamental or essential for a valid Muslim marriage such as offer and acceptance (ijab wa qabul), wali or a guardian for marriage as well as mahr or dowry. Other than that Islam also enact various laws for instance to tolerate polygamy as an alternative to the sexual promiscuity, promote procreation and prohibits abortion, enact law for the obligations of spouses, prescribe the requirement of $i d d a h$ for women, take care of the financial need of wife, children and other family members and the like. Islam also enacts rules and regulations that are conducive to the realization of the goal of Muslim marriage. (Sayed, 2013)

In pursues of achieving a successful marriage, the government also plays a significant role by enacting law pertaining marriage contract and its procedures. For example, Malaysia has enacted the Islamic Family Law Act which regulates the marriage contract in each state. Similarly, other countries have introduced laws pertaining to marriage contract, for instance, Pakistan and Philippines, both have the Code of Muslim Personal law.

Furthermore, by means of marriage human can fulfills his/her sexual needs free from related diseases, hence fulfilling his/her parental sense through having children. It also facilitates maintenance of the sense of security, self-content and chastity for both husband and wife. Men and women are created by Allah SWT as company for one another and to procreate and live in peace and tranquility in accordance with Allah's SWT guidance and His Messenger's directions. It is stated in the Holy Qur'an that Allah SWT has created man and woman as mates for one another so that they can live together and lead a peaceful life. This is a sight of greatness of Allah SWT. This is clear from the following Quranic verse:

And among His signs is that He created for you mates from among yourselves, that you may dwell in tranquility with them, and He has put love and mercy between your hearts. Undoubtedly in these are signs for those who reflect. (Qur'an, 30:21)

And Allah has made for you your mates of your own nature, and made for you, out of them, sons and daughters and grandchildren, and provided for you sustenance of the best. (Qur'an, 16:72)

From the above mentioned verses it is clear that, marriage is one of the most virtuous and approved institutions. Other religion do not view marriage in the same manner, for they stress more on celibacy or monasticism and consider it as a great virtue and a means of deliverance. The prophet (PBUH) also stresses the significance of marriage remarkably saying: "O you young men! Whoever of you is able to marry should marry, for it will help him lowering and not gazing at women hence, guarding his modesty." (Bukhari, 1400)

One can clearly understand the benefit of marriage, as mentioned in the forgoing saying of the prophet, to be the cherishing of modesty which is regarded as a great virtue by the Prophet. This is also supported with another saying of the prophet PBUH "Modesty is part of faith." (Muslim, n. d.)

The institution of marriage is greatly emphasized in Islam and its importance is made crystal clear. This is evident from another tradition of the prophet in which he states "Marriage is my practice. Whosoever avoid it is not my follower/from me." (Sulaiman, 1987) Imam Ahmad also has reported that the Prophet PBUH said, "The evils amongst you are those who stay single and mean are those who die in a state of staying single." (Hassan, 1985) 
In the light of these Qur'anic injunctions and the prophetic traditions it can be concluded that Islam holds the value and significance of marriage in a high esteem. Marriage as understood in Islam embodies two different aspects of human life: aspect of 'ibadah (worship) of Allah and aspect of mu'amalah (transactions between human beings). Considering marriage as an act that pleases Allah SWT, it can be classified as Ibadah, for, the husband and wife love each other in accordance with Allah's SWT commandments and make efforts to continue the human race and rear and nurse their children to become true servants of Allah.

On the other hand, the mu'amalah aspect of marriage is evident from the fact of its being a lawful response to the human biological instinct and need to have sexual intercourse and to procreate children. However, to regulate and control human sexual behavior, Islamic law has provided a set of detailed rules for rendering this response into a living human institution supported by a whole framework of rights and duties for the spouses and their offspring. These aspects are beautifully articulated and explained in a tradition of the Prophet which is narrated by Anas that the prophet PBUH said, "When a man marries, he has fulfilled half of his religion, so let him fear Allah regarding the remaining half." (Ahmad, 2003) Marriage constitutes half of the faith of a Muslim for it protects him against adultery, fornication, homosexuality and other related crimes.

\section{The Purposes of Marriage}

Marriage in Islam has multiple purposes such as, spiritual calmness, cooperation and partnership in accomplishing the divine obligation. Islam as a primordial state of human nature embodies all aspects of man ranging from physical, spiritual to intellectual and caters for them in a most balanced way.

Although, marriage fulfills one's material needs in adequate and orderly manner, nevertheless, as mentioned earlier, tranquility and peace that is achieved through successful union is considered its primary objective. Besides, tranquility and peace marriage results in a partnership between males and females by means of which they can achieve goodness and fulfill the divine mandate. As Allah SWT has stated in the Quran:"

The believers, males and females, are partners of one another; they shall jointly enjoin all that is good and counsel against all that is evil. (Qur'an, 9:71)

Based on the above premise the purposes of the marriage can be illustrated as follow;

\subsection{Union between Male and Female}

Marriage unites man and woman in a lofty and dignified manner. It is a divine law that nothing can ever carry out its obligation independently. Allah SWT has created all things in a manner that they are dependent on one another of its kind. They could not function independently and need each other's help and assistance in complementing one another. To explain this example from the field of electricity can be elaborate here. In the field of electricity, it is necessary for both positive and negative poles to be in contact in order to induce an electric current, hence, yielding light, heat and motion. Similarly, the existence of electrons and protons within an atom and their contact is a necessary requirement for the existence of an atom. In plants, the production of more plants, fruits and seeds heavily depend on the interaction of pollen grain and a flower's stigma; the former carrying male gametes hence fertilize the later. In the same manner, in order to produce the male and female animals have to be in contact with each other. These universal laws are highlighted in the following Quranic verses:

We have created all things by pairs that haply ye may contemplate (51:49)

Glorious is Him who has created all the sexual pairs, of that which the earth grows, and of themselves, and of that which they know not. (36:36)

Along with these universal laws, Allah, SWT has ordained a transcendent tradition according to which a man and a woman can be united in a manner that befit their lofty position and status, namely through marriage. This is an advantage of marriage which can unite woman and man. Islam prohibits same gender relationship such as marriage between men or marriage between women. However, it is contrary with the Europe countries which permit the same gender marriage.

\subsection{Reproduction/Procreation}

Marriage naturally results in reproduction which is necessary for the continuity and existence of human generation on the earth. It is a blessing of Allah's that he granted man a mate of his own kind to live with and be together saying.

And Allah hath provided you wives of your own kind, and has given you, from your wives, descendent, and has provided you with good provision. Is it then in vanity that they believe and in the grace of Allah that they disbelieve? (16:72) 
For the same reason the Prophet Zakariyyah (Zachariah, peace be upon him) appealed to Allah saying:

(And Zachariah, when he appealed to his Lord: saying "My Lord! Leave me not childless, though Thou art the best of inheritors,) (21:89) and (Lo! I fear my kinsfolk after me, since my wife is barren. Oh, my Lord gives me a successor. Who should be my inheritor and inheritor (also) of the house of Jacob. And make him, my Lord, acceptable (unto Thee) (Maryam 19:5-6)

Ibrahim (Abraham), the father of the Prophets (peace be upon them), too supplicated to Allah saying: My Lord! Vouchsafe me of the righteous. So We gave him tidings of a gentle son. (37:100-101)

Consequently, reproduction play a significant role in grow and development of nations. It enables nations to utilize their potential to a greatest extant and manages their defense capability in an effective manner. The Prophet PBUH said "Get married (and reproduce) for I will boast of your large numbers in front of other nations (on Judgment Day) and do not apt to-celibacy or-monasticism." (al-Baihaqi, 2003). For it is by the means of reproduction that the whole humanity throughout the globe, until the point when life comes to an end, is preserved.

\subsection{Completion of Faith}

Marriage complements one's faith, in the sense that it help one avoid looking at other women, hence, preserving his chastity. It provides him with a lawful means to fulfill his sexual desire, thus, preventing him from committing adultery. This is crystal clear from the saying of the prophet PBUH pertaining marriage "It save one from looking at what one should not, or it prevent one from being involved in adultery." (Majah, n. d.) Furthermore, there are other negative effects that one can diagnose in a sexual related disease caused by sexual intercourse with multiple partners. (Sayid, 2013) It can be avoided through valid marriage. The prophet PBUH also made it clear that, "If a Muslim is granted by Allah with a righteous wife, this assists him in preserving half of his (faith). Therefore, he should, fear Allah in respect of the other half." (Hakim, 1990)

\section{Happiness and Joy}

Marriage besides preserving a Muslim faith, attain his worldly happiness which Islam encourages. Faith and happiness are crucial elements of one's personality. They can help one in his struggle of elevating his souls and acquiring high degrees of religiousness. This is highlighted by the prophet PBUH as reported by Imam Muslim, "The entire world is-source of-pleasure, and the best-source of-pleasure of the world is the righteous woman." (Muslim, n. d.) There is another tradition with similar connotation: "there are four things that bring one joy: a righteous spouse, a commodious house, a religious neighbor and a comfortable means of riding" (Bayhaqi, 2003).

\section{Establishment of Family}

Marriage is the sole mechanism for establishing family life. No respectable human society could ever exist without family, the fundamental unit of the structure of society. Family is the avenue where close relation emerges such as parental and maternal relations, parent and child relation as well as that of sibling's relations. In addition to these relations, it also inculcates earnest sense of love and compassion, altruism, kindness, care and cooperation in a Muslim.

\section{Boosting Social Relations}

Marriage enhances and strengthens social bonds among the individual members of society. For, it expands the range of family by adding new relatives to family structure through inclusion of in-laws and children's aunts and uncles. Thus, through such extension more and more people can enjoy the feelings of love, belonging and social closeness in the society. Allah views both kinship and marriage relations to be extremely important and encourage the family members to maintain both kinship and marriage relations strongly. Allah, Exalted be He, says: (And Allah is who has created man from water, and has selected for him relation by blood and relation by marriage; for thy Lord is ever Powerful.) (Al-Furqan, 54)

\section{Sense of Responsibility}

Marriage nurtures human character by instilling a sense of responsibility in him and enabling him to bear his responsibility as a husband and a father. In the same manner, marriage inculcates in a woman the sense of responsibility as a wife and a mother. Unfortunately, some people avoid marriage due to distorted mentality and tendency of not willing to bear their responsibly. Thus, living like grown-up children without meaningful relation, house and responsibility. They lose their worth to live a meaningful life and prove to be good for nothing. These all is due to ignorance of the significance of marriage which represents a strong commitment and a shared responsibility between a man and a woman since their first day together. Allah, Exalted be He, says: 
Men are guardian of women, because Allah has made men-some of them-to excel the other, for, they spend of their property (for the support of women). So good women are those women who are obedient and guard in secret what Allah has guarded. (Qur'an, 4:34)

It is mentioned in a prophetic tradition that everyone is a guardian and responsible for those who are under his charge; for example, the man in his home, is a guardian and responsible for his household; the woman, concerning her husband's property, is a guardian and responsible for what she is entrusted with." (Muhammad, 1422)

Consequently, Islam also prescribe the obligation of husband towards his wife such as duty of care, avoiding foul language, giving her protection, duty of financial support and etc. Besides that, wife also must perform her obligation towards her husband like being loving and tolerant with her husband, avoiding asking divorce without valid reason and others obligations stated in Qur'an and the tradition of the Prophet PBUH Thus, husband and wife have to take responsibility towards all of these obligations respectively. (Sayed, 2013)

\section{Confidence and Assurance}

A married person is more capable of focusing fully on performing his job professionally, for, he is motivated by the fact that there is someone who care about him and take care of the household and his children. Thus, having peace of mind he can do his job properly and a productive and excellent manner. At the contrary, a person who is not married his mind is not focused but disintegrated. For, his mind is preoccupied with thinking about his work and home, and the burden of securing his food and clothes.

\section{Conclusion}

To conclude, provision of a healthy environment for the maintenance of cordial relations and reciprocal love between the spouses can be considered as the primary objective of contract of marriage. Beside provision of healthy environment for the establishment of cordial relations between spouses it has some other purposes manifested in the provision of company to each other, loving one another, procreation of children and living in peace and tranquility. In fact marriage is a channel through which emotional and sexual feeling can be gratified and tension be reduced. It comes under the form of Ibadah (worship) because it is act of obeying Allah and his messenger and the only legal means through which the male and female can be united, hence, living together as husband and wife. Hence marriage being a mithaq a (solemn covenant) requires a full commitment and knowledge of what it embodies. For, it nurtures human character by instilling a sense of responsibility in him and enabling him to shoulder his duty, as a husband and a father. In the same manner, marriage inculcates in a woman the sense of responsibility which she has to shoulder, as a wife and a mother. Such a responsibility requiring a strong determination should be taken seriously to avoid undesired consequences. Marriage is the sole mechanism for establishing family life. No respectable human society could ever exist without family, the fundamental unit of the structure of society. It is a divine law that nothing can ever perform its duty independently. Allah SWT has created everything in pair and they are in need of one another for their complementation. Marriage unites man and woman in a lofty and dignified manner due to this function it is considered as one of the most virtuous institutions in Islam, a unique position which other religion lack. For, they perceive celibacy or monasticism as a great virtue and means of attaining salvation. Marriage naturally results in reproduction which is necessary for the continuity and existence of human generation on the earth. In addition, it preserves a Muslim faith and attains his worldly happiness encouraged by Islam. Faith and happiness are crucial elements of one's personality. Marriage is considered as a form of 'ibadah (worship) for, it is an act which is in full compliance with the commandments Allah SWT hence incurring His pleasure.

\section{References}

Abdullah, I. M. A., \& Al-Qazwini, M. B. Y. (n. d.). Sunan Ibn Majah. Juz 1. Dar Ihya' al-Kutub al-'arabiah.

Al-Baihaqi, \& Al-Husain, A. B. A. B. (2003). Shua'bu al-Iman. Juz 7. Riyadh: Maktabah ar-Rusyd.

Al-Baihaqi, A. B., \& Al-Husain, A. B. (2003). Al-Sunan al-Kubra. Juz 7. Beirut: Dar al- Kutub al-Ilmiah.

Al-Bukhari, M. B. I. (1400h). Sahih al-Bukhari. Damsyik: Dar Tauq al-Najah.

Al-Fiyumi, M. I. (1994). Tarikh al-Fikr al-Dini al-Jahili. Dar al-Fikr al-'A Arabi.

Al-Hakim, M. B. A. (1995). Al-Mustadrak 'ala sohihaini. Juz 2. Beirut: Dar al-Kutub al-Ilmiah.

Al-Qur'an, Sulaiman bin Abd al-Qawi bin al-Karim al-Tufi As-Sarsari, Al-Rabi', A., \& Al-Din, N. (1987). Sharh Mukhtasar al-Raudah, Juz 3. Muassasatur Risalah.

Haneef, S. S. S. (2013). Shariah Objectives of Marriage: The Significance in Stabilising Families. [2013] 1 MLJ 
clxiv. Malayan Law Journal Articles.

Ibrahim, A. (1997). Family Law in Malaysia (3rd ed.). Kuala Lumpur: Malayan Law Journal Sdn Bhd.

Muslim bin al-Hajjaj Abu al-Hasan al-Qushairi an-Nisaburi. (n. d.). Al-Musnad as-Sahih al-Mukhtasor Binaqli al-adl 'An al-adl ila Rasulillah Salallahu 'Alihi wa Sallam. Juz 2. Beirut: Dar Ihya at-Turath al-Arabi.

Yahya, M. H. A. (1985). Ahdaf al-Tashri' al-Islami. Jordan: Dar al-Furqan.

\section{Copyrights}

Copyright for this article is retained by the author(s), with first publication rights granted to the journal.

This is an open-access article distributed under the terms and conditions of the Creative Commons Attribution license (http://creativecommons.org/licenses/by/3.0/). 